Article

\title{
Microbial Sensing and Removal of Heavy Metals: Bioelectrochemical Detection and Removal of Chromium(VI) and Cadmium(II)
}

\author{
Reham A. Alfadaly ${ }^{1}$, Ashraf Elsayed ${ }^{1, *(D)}$, Rabeay Y. A. Hassan ${ }^{2,3}\left(\mathbb{D}\right.$, Ahmed Noureldeen ${ }^{4}$ (D) Hadeer Darwish ${ }^{5}$ \\ and Ahmed S. Gebreil ${ }^{1}$
}

1 Botany Department, Faculty of Science, Mansoura University, Elgomhouria St., Mansoura City 35516, Egypt; rehamalfadaly123@yahoo.com (R.A.A.); bio_botany@yahoo.com (A.S.G.)

2 Nanoscience Program, University of Science and Technology (UST), Zewail City of Science and Technology, 6th October City, Giza 12578, Egypt; ryounes@zewailcity.edu.eg

3 Applied Organic Chemistry Department, National Research Centre (NRC), Dokki, Giza 12622, Egypt

4 Department of Biology, College of Sciences, Taif University, P.O. Box 11099, Taif 21944, Saudi Arabia; a.noureldeen@tu.edu.sa

5 Department of Biotechnology, College of Sciences, Taif University, P.O. Box 11099, Taif 21944, Saudi Arabia; hadeer@tu.edu.sa

* Correspondence: ashraf-badawy@mans.edu.eg; Tel.: +20-106-906-0801

Citation: Alfadaly, R.A.; Elsayed, A.; Hassan, R.Y.A.; Noureldeen, A.; Darwish, H.; Gebreil, A.S. Microbial Sensing and Removal of Heavy Metals: Bioelectrochemical Detection and Removal of Chromium(VI) and Cadmium(II). Molecules 2021, 26, 2549. https://doi.org/10.3390/ molecules26092549

Received: 6 March 2021

Accepted: 13 April 2021

Published: 27 April 2021

Publisher's Note: MDPI stays neutral with regard to jurisdictional claims in published maps and institutional affiliations.

Copyright: (c) 2021 by the authors. Licensee MDPI, Basel, Switzerland. This article is an open access article distributed under the terms and conditions of the Creative Commons Attribution (CC BY) license (https:// creativecommons.org/licenses/by/ $4.0 /)$.

\begin{abstract}
The presence of inorganic pollutants such as Cadmium(II) and Chromium(VI) could destroy our environment and ecosystem. To overcome this problem, much attention was directed to microbial technology, whereas some microorganisms could resist the toxic effects and decrease pollutants concentration while the microbial viability is sustained. Therefore, we built up a complementary strategy to study the biofilm formation of isolated strains under the stress of heavy metals. As target resistive organisms, Rhizobium-MAP7 and Rhodotorula ALT72 were identified. However, Pontoea agglumerans strains were exploited as the susceptible organism to the heavy metal exposure. Among the methods of sensing and analysis, bioelectrochemical measurements showed the most effective tools to study the susceptibility and resistivity to the heavy metals. The tested Rhizobium strain showed higher ability of removal of heavy metals and more resistive to metals ions since its cell viability was not strongly inhibited by the toxic metal ions over various concentrations. On the other hand, electrochemically active biofilm exhibited higher bioelectrochemical signals in presence of heavy metals ions. So by using the two strains, especially Rhizobium-MAP7, the detection and removal of heavy metals $\mathrm{Cr}(\mathrm{VI})$ and $\mathrm{Cd}(\mathrm{II})$ is highly supported and recommended.
\end{abstract}

Keywords: biosensing of heavy metal contaminants; microbial electrochemistry; biofilm formation; hexavalent chromium; $\mathrm{Cr}(\mathrm{VI})$

\section{Introduction}

There are a number of pollutants and toxic agents, such as fertilizers, pesticides, and heavy metals, which extremely disturb the living and non-living systems. Heavy metals, such as $\mathrm{Hg}, \mathrm{Pb}, \mathrm{Cr}$ and $\mathrm{Cd}$, are causing specific toxicity symptoms even in low concentrations of about $1.0-10 \mathrm{mg} / \mathrm{L}$ because they are being accumulated in the soft tissues [1-4]. The toxicity of heavy metal may result from alterations of numerous physiological processes caused at cellular/molecular level by deactivating enzymes functions, blocking active sites or functional groups of metabolically significant molecules, displacing or substituting for essential elements and disrupting membrane integrity [5-7]. $\mathrm{Cr}(\mathrm{VI})$ is carcinogenic and toxic even in small amounts which diffuses through the epidermis and reduces to $\mathrm{Cr}$ (III) that interacts with nuclear enzymes, proteins nucleotides and DNA [8]. Ingestion of $\mathrm{Cr}$ ions in large amounts can cause stomach upsets and stomach ulcers, convulsion, kidney and liver damage and even death [9]. On the other hand, cadmium is extremely toxic to 
humans by bioaccumulation in the kidney and the liver through the food chain $[10,11]$. The level of cadmium and chromium should not be beyond the permissible limit, $\leq 0.003 \mathrm{mg} / \mathrm{L}$, and $\leq 0.05 \mathrm{mg} / \mathrm{L}$, respectively [12].

For detecting acute toxicity caused by heavy metals, pesticides and organic solvents, several biochemical assays were applied based on the function of microorganisms [13], bacteria [14], antibodies [15] and enzymes [16]. Indicator microbes provide a simpler method [17] because microorganisms have biosorption capabilities as well as they are easy to culture in a short generation time so their response to toxic substances is quite rapid [18]. Soil bacteria Rhizobium sp. is one of the major elements for the maintenance of soil fertility where it has the ability to fix nitrogen in leguminous plants [19-21]. Symbiotic nitrogen fixation is sensitive to heavy metals in soil [22]. Rhizobium can be used as an indicator organism to several toxic chemicals, including heavy metals [23] and for effective, economical and eco-friendly metal bioremediation technologies [24] whereas Sinorhizobium meliloti has high tolerance ability for various heavy metals [25]. Cell wall components of microorganisms and pigments could have active metal sorption sites that are able to accumulate cadmium and lead simultaneously [26-29]. Amongst biosensors used techniques for online evaluation of microbial activity and intra/extracellular functions, microbial electrochemical systems (MESs) were developed and applied in many applications [30-35].

The microbial electrochemical-based biosensor can lead to a cost-effective, simple and repeatable measurement, which can provide rapid screening of heavy metals and their toxic effects in water-based environments. Thus, this work aims to develop microbial electrochemical systems that support the rapid detection for the microbial removal of $\mathrm{Cr}(\mathrm{VI})$ and $\mathrm{Cd}(\mathrm{II})$ using a selection of viable microbial cells.

\section{Results and Discussion}

\subsection{Effect of the Metal Ions on the Growth and Cell Viability of the Selected Microbes}

Classical monitoring of the untreated cells of the Rhodotorula ALT72 and RhizobiumMAP7 showed that the Rhodotorula ALT72 has faster growth rate with higher biomass production, whereas the stationary state was observed after $30 \mathrm{~h}$ (Figure 1A). On the other hand, resistivity or sensitivity of the selected microbes towards the toxic effects of chromium and cadmium ions was studied among several concentrations of the metal ions $(0,1,10,20,30,40$ and $50 \mathrm{mg} / \mathrm{L})$. Normal growth was observed at the low concentration, while the growth inhibition was obtained when the concentration was exceeded $10 \mathrm{mg} / \mathrm{L}$ for chromium, and $20 \mathrm{mg} / \mathrm{L}$ for cadmium (As can be depicted from Figure 1B,C). Taking into consideration, chromium and cadmium have different toxic effects on the selected two strains. In that sense, Rhizobium was less sensitive to the toxic effects of chromium(VI), as can be seen from Figure 1D.

As is shown in (Table 1), both of the Rhodotorula-ALT72 and Rhizobium-MAP7 were exposed to several concentrations of both metal ions, while the uptake rate of heavy metal was analyzed by considering the remaining concentration in the supernatants of the microbial culture. At the highest dose, i.e., the lethal concentration which is $50 \mathrm{mg} / \mathrm{L}$, Rhodotorula-ALT72 still survived and showed an uptake of Cd ions with $1.274 \%$. However, the Rhizobium-MAP7 did not show any capacitance of removal at this concentration. Regardless the lethal concentration, Rhizobium-MAP7- has higher removal efficiency than the Rhodotorula-ALT72, whereas the highest removal efficiency was reached $75 \%$ by the Rhizobium-MAP7 compare to $63.5 \%$ by the Rhodotorula-ALT72 at the concentration of $0.1 \mathrm{mg} / \mathrm{L}$. In the essence of chromium(VI) removal, the result shown in Table 1 exhibited the higher efficiency of the $\mathrm{Cr}(\mathrm{VI})$ by the Rhizobium-MAP7 whereas the maximum capacity of removal was about $45 \%$ at the concentration of $0.1 \mathrm{mg} / \mathrm{L}$. Nevertheless, both strains could not survive at the lethal dose; therefore, zero- $\%$ of removal was attained. 

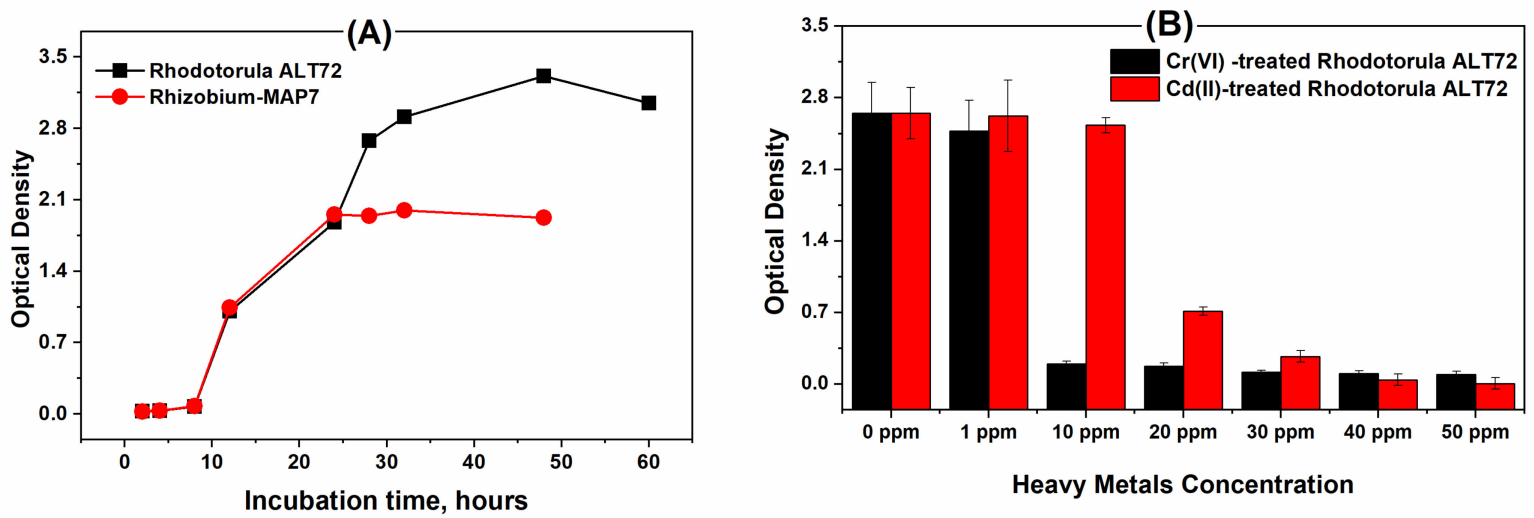

(C)
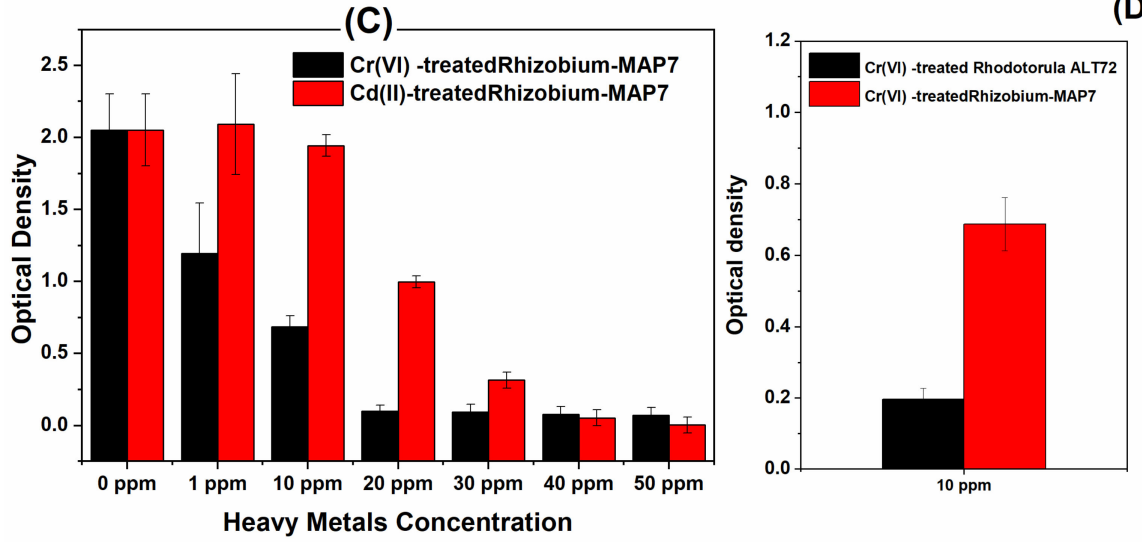

(D)

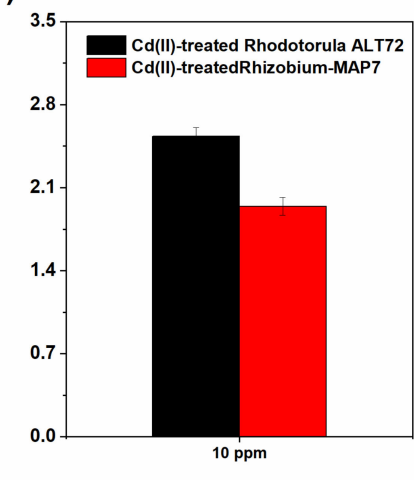

Figure 1. (A) Typical growth curves of untreated cells of Rhodotorula ALT72 and Rhizobium-MAP7, (B) effect of metal ions concentrations on the growth inhibition of Rhodotorula ALT72, (C) sensitivity of Rhizobium-MAP7 to Cr(VI) and Cd(II) different concentrations and (D) responses of Rhodotorula ALT72 and Rhizobium-MAP7 to a single concentration of Cr(VI) and Cd(II). The results recorded after $48 \mathrm{~h}$ for the Rhizobium-MAP7 and $60 \mathrm{~h}$ for the Rhodotorula ALT72.

Table 1. Measuring the remaining concentrations of metal ions in the microbial supernatants after culturing the Rhodotorula ALT72 and Rhizobium-MAP7 in synthetic contaminated liquid media. Metal ions concentrations were detected by Atomic Absorption Spectroscopy.

\begin{tabular}{|c|c|c|c|c|c|}
\hline \multicolumn{2}{|c|}{ Heavy Metals Conc. } & \multicolumn{2}{|c|}{ Rhodotorula sp. } & \multicolumn{2}{|c|}{ Rhizobium sp. } \\
\hline Type & $\begin{array}{c}\text { Initial } \\
\text { Concentration } \mathrm{mg} / \mathrm{L}\end{array}$ & $\begin{array}{c}\text { Remaining } \\
\text { Concentration } \mathrm{mg} / \mathrm{L}\end{array}$ & Removal \% & $\begin{array}{c}\text { Remaining } \\
\text { Concentration } \mathrm{mg} / \mathrm{L}\end{array}$ & Removal \% \\
\hline \multirow{5}{*}{$\mathrm{Cr}(\mathrm{VI})$} & 0.01 & 0.0064 & $36.00 \%$ & 0.0056 & $44.00 \%$ \\
\hline & 0.10 & 0.085 & $14.70 \%$ & 0.055 & $44.90 \%$ \\
\hline & 1.00 & 0.95 & $5.20 \%$ & 0.85 & $15.03 \%$ \\
\hline & 10.00 & 9.5 & $5.07 \%$ & 9.73 & $2.70 \%$ \\
\hline & 50.00 & 50.00 & $0.00 \%$ & 50.00 & $0.00 \%$ \\
\hline \multirow{5}{*}{$\mathrm{Cd}(\mathrm{II})$} & 0.01 & 0.0084 & $63.00 \%$ & 0.0048 & $52.00 \%$ \\
\hline & 0.10 & 0.0365 & $37.50 \%$ & 0.025 & $74.70 \%$ \\
\hline & 1.00 & 0.626 & $16.39 \%$ & 0.51 & $48.93 \%$ \\
\hline & 10.00 & 9.85 & $1.45 \%$ & 9.08 & $9.21 \%$ \\
\hline & 50.00 & 49.87 & $1.27 \%$ & 50.00 & $0.00 \%$ \\
\hline
\end{tabular}

\subsection{Testing the Cell Responses to the Metal Ions}

Usually, toxic effects of metal ions on the microbial activity are detected by monitoring the inhibition in the growth rate. Nevertheless, following up the changes in cell populations is a tedious and time-consuming process. Hence rapid screening of toxic effects on the cell viability is highly desirable. Therefore, a quick cell viability assay was here implanted using the WST which measures the metabolic activity along with the electron transport chain efficiency, [36]. Accordingly, Rhodotorula ALT72 and Rhizobium-MAP7 were treated with different concentrations of $\mathrm{Cr}(\mathrm{VI})$ or $\mathrm{Cd}$ (II) $(0.1,1,10$ and $50 \mathrm{mg} / \mathrm{L})$. As depicted in Figure 2A, Rhodotorula ALT72 was more sensitive to the heavy metals than the Rhizobium-MAP7, since 
its cell viability was strongly inhibited using several concentrations. Nevertheless, the resistivity of the Rhizobium-MAP7 to the heavy metals was obvious as the cell viability was not affected after the heavy metal treatments, as can be shown in Figure 2B. Surprisingly, chromium ions were lethal even at the moderate concentration $(1 \mathrm{mg} / \mathrm{L})$ when a sensitivity bacterial strain was treated. This result was demonstrated in Figure 2C. Thus, the use of the Rhizobium-MAP7 as a target strain for the high-affinity detection and capture of heavy metal contaminants is achieved to the current extent.
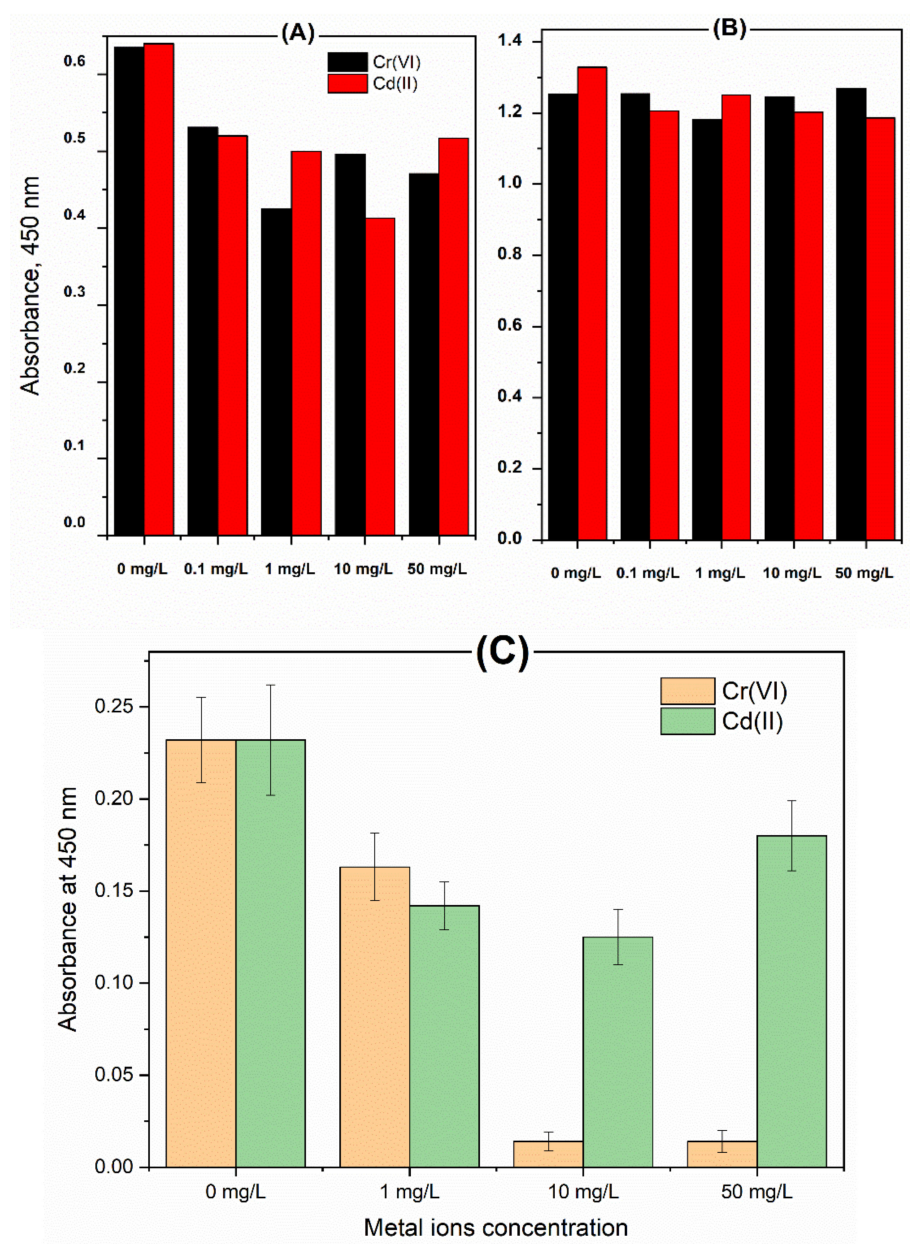

Figure 2. Testing the cell viability of treated Rhodotorula ALT72 (A) and Rhizobium-MAP7 (B) using WST-test and (C): testing the cell viability of Pantoea agglomerans using WST-test.

\subsection{Biosensing the Microbial Response to Heavy Metals Exposure}

Microbial electron transport chain (METC) represents the most important compartment in the living systems, since the oxidation of degradable organic substrates is the main energy source of live microbial cells [37]. Therefore, measuring the efficiency of microbial respiration and the activity of the electron transport chain are considered main indicators of cellular activity, as they are essential for the replication and proliferation of aerobic organisms [38]. Consequently, the electron transfer process from living-microorganisms towards electrodes in microbial electrochemical systems (MESs) is exploited in microbial fuel cells or diagnostic tools for rapid assessment of microbial activity [39-41]. In these regards, many MES approaches were designed and tested for biological purposes [42-45]. The electrical current value generated by the MESs is directly proportional to the number of viable microbial cells that are incorporated in MESs. On the other hand, non-viable or non-cultivable living cells do not have electrochemical contribution, and thus, they do not generate electrochemical signals. Thus, the resulting bioelectrochemical responses reflect the extent of anodic respiration, intracellular redox reactions (e.g., intracellular 
enzyme activities) and/or other biological interactions [46,47]. Since the bioelectrochemical responses can be linked to microbial processes, the design of high-performance MESs has gained increasing attention due to their many promising applications in the environment, energy and biomedical fields [48]. Formation of biofilms at the sensor's surface has been used for determining the microbial responses to the toxic effects of the utilized heavy metals. The main idea behind the bioassay is the receiving of electrons directly from the colonized microorganisms on the conductive sensors surfaces. The obtained curves are known as voltammograms, whereas the generated electric current is expressing the number of viable cells participating in the bioelectrochemical reactions. In this regard, any decrease in the generated current is referring to the encountered toxic effects. To that end, the selected strained were treated with the metal ions and were incubated with the sensors for two weeks in order to allow the formation of biofilms at the sensor's surface. Accordingly, bioelectrochemical performances were analyzed. The results revealed in Figure 3 demonstrated the decrease in the activity of the biofilm supported by the electrode surfaces due to the existence of metal ions in the microbial culture. As displayed in Figure $3 \mathrm{~A}$, the interactions or the communication between the targeted bacterial and the sensor's surface have been measured in presence of two different concentrations (10 and $20 \mathrm{mg} / \mathrm{L}$ ) of the $\mathrm{Cr}(\mathrm{VI})$ and $\mathrm{Cd}(\mathrm{II})$. To that end, lower electrochemical signals were acquired from the cell of Rhodotorula-ALT72 treated with cadmium concentration. Nevertheless, the untreated cells of Rhodotorula-ALT72 produced higher electrochemical signals, i.e., about two-fold increase in the electrochemical readouts. On the other hand, Figure $3 \mathrm{~B}$ demonstrated the voltammetric responses of chromium-treated vs the untreated cells of Rhodotorula-ALT72 ions. Pronounced increase in the voltammetric signals were obtained from the untreated cells, and the inhibition of the electrochemical signals were dependent on the heavy metal concentrations.

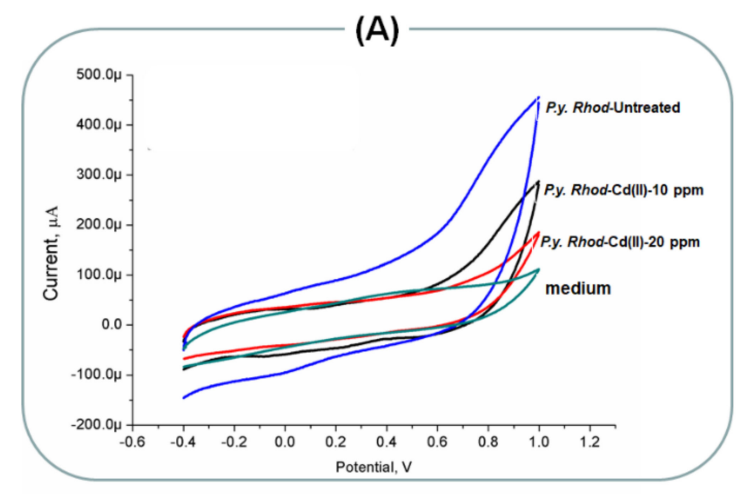

(B)

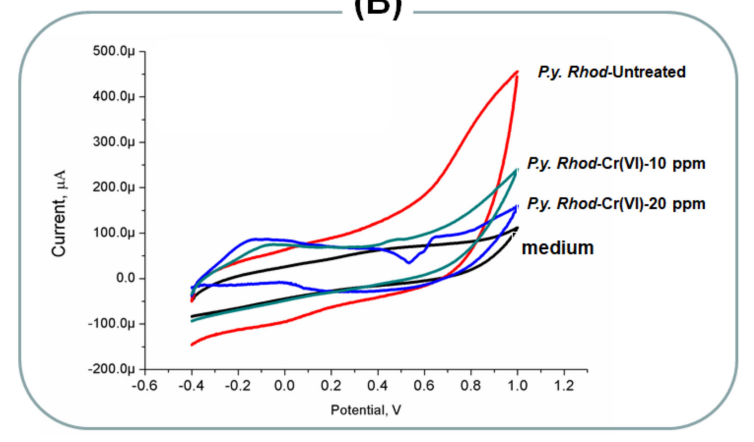

Figure 3. (A) Bio-electrochemical responses of biofilm formed Rhodotorula ALT72 treated with different concentrations of $\mathrm{Cd}(\mathrm{II})$. The untreated cells were considered as the positive control and (B) bio-electrochemical responses of biofilm formed Rhodotorula treated with different concentrations of $\mathrm{Cr}(\mathrm{VI})$. The untreated cells were considered as the positive control. 


\subsection{Rhizobium Bioelectrochemical Performance}

Following the same manner, the interaction of Rhizobium-MAP7 with the $\mathrm{MnO}_{2}$ nanorods were measured in presence of two different concentrations (10 and $20 \mathrm{mg} / \mathrm{L})$ of the $\mathrm{Cr}(\mathrm{VI})$ and $\mathrm{Cd}(\mathrm{II})$. To that effect, the voltammetric signals of the treated cells were much lower than obtained by the untreated cells, as can be figured out from Figure 4. However, the toxic effects were more strongly sounding here if we compare these results with those obtained from the Rhodotorula. These findings revealed the stronger sensitivity of Rhodotorula to the toxic effects of the tested heavy metals.

(A)

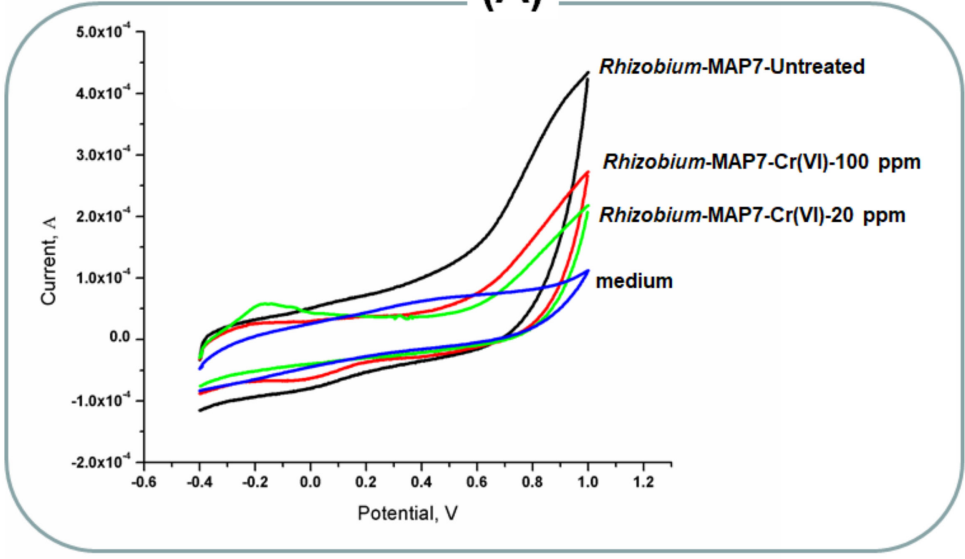

(B)

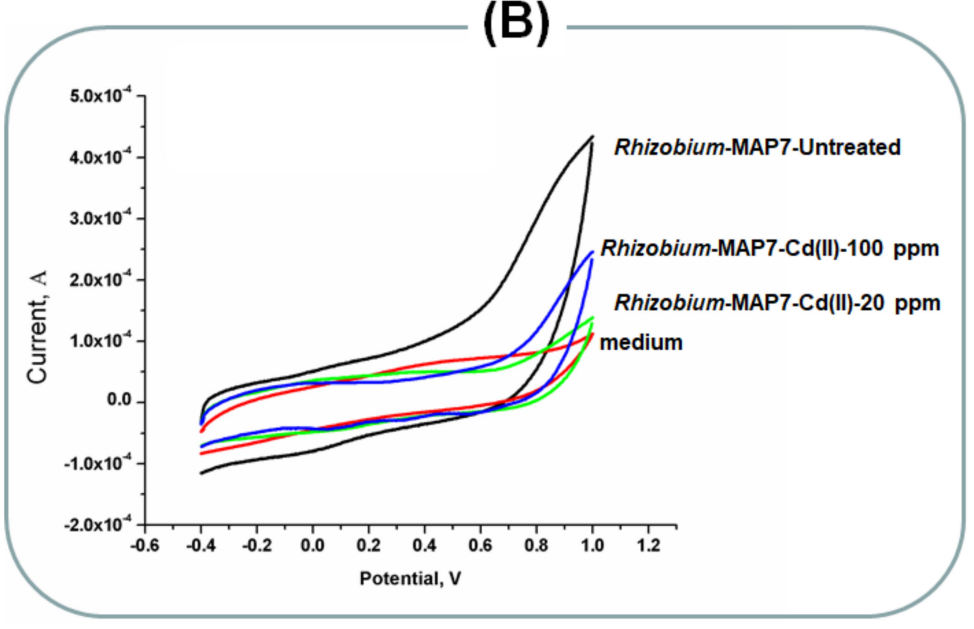

Figure 4. (A) Bio-electrochemical responses of biofilm formed Rhizobium-MAP7 treated with different concentrations of $\mathrm{Cr}(\mathrm{VI})$. The untreated cells were considered as the positive control and (B) bioelectrochemical responses of biofilm formed Rhizobium-MAP7 treated with different concentrations of Cd(II). The untreated cells were considered as the positive control.

P. agglumerans biofilm formation and bioelectrochemical responses to $\mathrm{Cr}(\mathrm{VI})$ and $\mathrm{Cd}(\mathrm{II})$ ions. To show the big difference between the sensitive and resistive of microbial strains towards the toxic effects of heavy metals, P. agglumerans was treated with cadmium, and chromium ions and their bioelectrochemical performances were put in a comparison with the above discussed two microbial strains (the Rhizobium and the Rhodotorula). The obtained results were amazing (As shown in Figure 5), since the treated cells with the moderate concentrations of heavy metals did not respond electrochemically, and their electrode interaction was not detected. Worthwhile, the untreated culture of P. agglumerans was responding efficiently. 
(A)

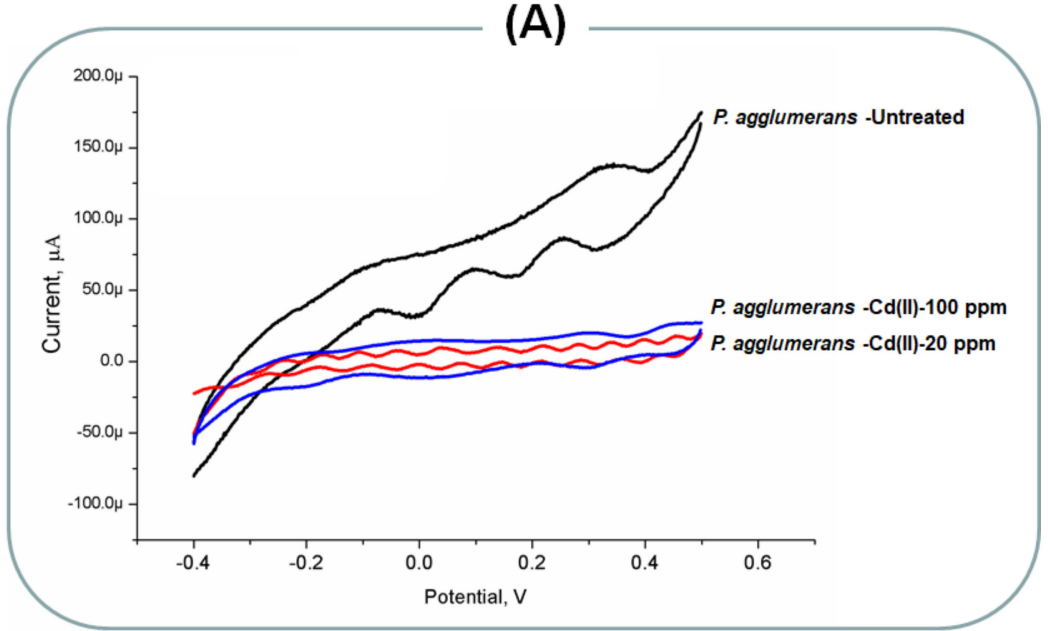

(B)

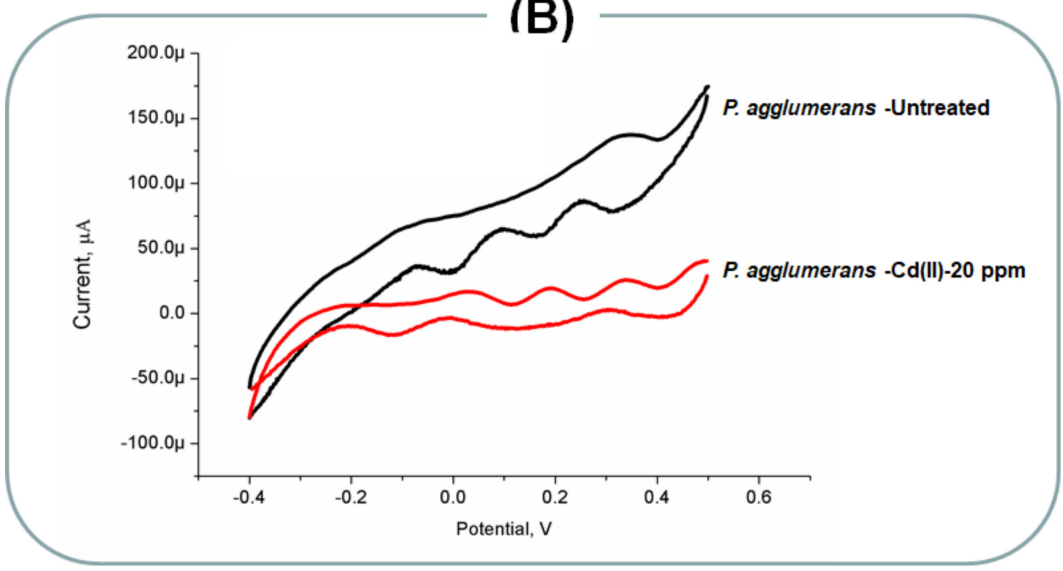

Figure 5. (A) Bio-electrochemical responses of biofilm formed P. agglumerans treated with different concentrations of $\mathrm{Cd}(\mathrm{II})$. The untreated cells were considered as the positive control and (B) bioelectrochemical responses of biofilm formed P. agglumerans treated with $\mathrm{Cr}(\mathrm{VI})$. The untreated cells were considered as the positive control.

Previously, Rhizobium has been used as an indicator organism to several toxic chemicals including metallothioneins that can bind to metals ions through the thiol group of its cysteine residues [49-51]. On the other side, Rhodotorula showed the potential remove ions of heavy metals [52]. To that event, heavy metals ( $\mathrm{Hg}$ (II), $\mathrm{Cu}$ (II), and $\mathrm{Pb}$ (II) on the Rhodotorula mucilaginosa biofilm and planktonic cells was reported. In that study, minimum inhibitory concentration, minimum lethal concentration, as well as the minimum biofilm eradication concentration of the $R$. mucilaginosa were determined. The efficiency of heavy metal removal by planktonic cells from $R$. mucilaginosa was compared to the metal tolerance and removal efficiency by the biofilm. As they found in their study, biofilm tolerance was higher than the planktonic cells [52]. Thus, the use of biofilm formation for heavy metal removal and tracking the changes of metal ions concentration on-site was the main focus of our report with including two other heavy metal ions (i.e., the chromium and cadmium).

Biosensors and microbial electrochemical systems are currently exploited for heavy metal determination such as mercury, silver, copper, cadmium, lead, chromium and nickel $[48,53]$. From the microbiologically point of view, the existence of heavy metal pollutants in the medium can affect the electrochemically active microbes' metabolic activity, leading to decreased transfer of electrons and weak present manufacturing. Therefore, microbial electrochemical systems were applied for online monitoring the toxic effects on microbes [54]. 


\section{Materials and Methods}

\subsection{Microorganisms and Growth Conditions}

Gram-negative, nitrogen fixer soil bacterium Rhizobium-MAP7 was obtained from the Physiology Laboratory at the Faculty of Science, Mansoura University, Mansoura, Egypt. Unicellular pigmented yeasts Rhodotorula ALT72, was obtained from the Cell and Genetics Laboratory, Faculty of Science, Mansoura University. Both strains were grown in L.B medium at $28 \pm 1{ }^{\circ} \mathrm{C}$ with shaking at $150 \mathrm{rpm}$, while the $P$. agglumerans bacteria were grown in the L.B medium at $37^{\circ} \mathrm{C}$, obtained from Bacteria Laboratory, Faculty of Science, Mansoura University, Mansoura, Egypt, were used as controls. The growth rate estimated by measuring the optical density at wavelength $600 \mathrm{~nm}$ after $48 \mathrm{~h}$ of incubation for Rhizobium-MAP7, after 60-72 h for Rhodotorula ALT72 and after $24 \mathrm{~h}$ for P. agglumerans.

\subsection{Determination of Toxic Effects and the Minimum Inhibitory Concentration}

Sterilized LB media amended with different concentrations $(0,1,10,20,30,40$ and $50 \mathrm{mg} / \mathrm{L})$ of $\mathrm{Cr}(\mathrm{VI})$ or $\mathrm{Cd}(\mathrm{II})$ were inoculated with $100 \mu \mathrm{L}$ of the overnight cultures of Rhizobium-MAP7 or Rhodotorula ALT72 (individual treated flasks for each strain) at $28 \pm 1{ }^{\circ} \mathrm{C}, 150 \mathrm{rpm}$. To monitor the growth inhibition, optical density of each flask was determined photometrically at $600 \mathrm{~nm}$ after $48 \mathrm{~h}$ for the Rhizobium-MAP7 and $60 \mathrm{~h}$ for the Rhodotorula ALT72.

\subsection{Heavy Metals Analysis}

One hundred ppm of both chromium(VI) and cadmium(II) standard solutions were prepared from their potassium dichromate $\left(\mathrm{K}_{2} \mathrm{Cr}_{2} \mathrm{O}_{7}\right)$, and cadmium nitrate salt, respectively. Concentrations of $\mathrm{Cr}(\mathrm{VI})$ and $\mathrm{Cd}(\mathrm{II})$ were determined in bacterial culture supernatants by atomic absorption spectroscopy. Supernatants of the treated cells with various concentrations $(0.01,0.1,1,10$ and $50 \mathrm{mg} / \mathrm{L})$ of the metal ions were collected by centrifugation after different incubation times. The remaining concentrations of heavy metals in supernatants were compared with the basic concentrations of heavy metals before inoculation. The results were expressed as percentage of metal removal by using the following equation:

$$
\text { Metal ions removal }(\%)=\frac{\mathrm{Ci}-\mathrm{Cf}}{\mathrm{Ci}} \times 100
$$

where, $\mathrm{Ci}$ and $\mathrm{Cf}$ stand for the initial and final heavy metal concentrations respectively.

\subsection{Testing the Cell Proliferation Using WST-Test}

Proliferation along with the response of bacterial and fungal cell suspension towards the toxic effects has been determined colorimetrically using the chemical reagent of watersoluble-tetrazolium salt (WST). In test tubes, three $\mathrm{ml}$ of sterilized LB media has been amended with different concentrations $(0.1,1,10$ and $50 \mathrm{mg} / \mathrm{L})$ of both $\mathrm{Cr}(\mathrm{VI})$ and $\mathrm{Cd}(\mathrm{II})$ metal ions. Then, one mL inoculum culture of the Rhizobium-MAP7, Rhodotorula ALT72 and $P$. agglumerans were incubated under shaking for $30 \mathrm{~min}$ at $28 \pm 1^{\circ} \mathrm{C}$ for (Rhodotorula ALT72 and Rhizobium-MAP7) and $37^{\circ} \mathrm{C}$ for P. agglumerans. Accordingly, a solution of the water-soluble-tetrazolium salt (WST) reagent has been added to each test tube (i.e., $20 \mu \mathrm{L}$ from a stock solution of $10 \mathrm{mM}$ ). Afterwards, the absorbance at $450 \mathrm{~nm}$ has been measured and reflected as a zero time. Lastly, the stained microbial cultures have been incubated for further $30 \mathrm{~min}$ prior detecting the yellow color intensity that represents the cell viability and metabolic activity [39]. The inhibition in cell viability has been calculated according to the following formula:

$$
\text { Percent of inhibition }=\frac{\text { color response of treated cells }}{\text { color response of untreated cells }} \times 100
$$




\subsection{Susceptibility of Microorganism to Heavy Metals}

Cultures of $P$. agglomerans were treated with different concentrations of $\mathrm{Cr}(\mathrm{VI})$ and $\mathrm{Cd}(\mathrm{II})$, and incubated for $24 \mathrm{~h}$ at $37^{\circ} \mathrm{C}$, with shaking at $150 \mathrm{rpm}$. The optical density of each flask was determined at $600 \mathrm{~nm}$.

\subsection{Biofilm Formation and Bioelectrochemical Measurements}

All the microbial electrochemical investigations have been conducted with a voltammetric setup using a platinum wire as the counter electrode, a $\mathrm{Ag} / \mathrm{AgCl} / 3 \mathrm{M} \mathrm{KCl}$ as the reference electrode, and a $\mathrm{MnO}_{2}$-modified carbon electrode as the working electrode. The Gamry Potentiostat/Galvanostat/ZRA G750 system has been used for recording and analysis of the electrochemical assays. To investigate the response of microbial cells to different heavy metals, a suspension of Rhodotorula ALT72, Rhizobium-MAP7 and P. agglumerans as control were incubated with different concentrations of $\mathrm{Cr}(\mathrm{VI})$ and $\mathrm{Cd}(\mathrm{II})$ for two weeks to form mature biofilms at the working electrode surfaces. Consequently, at different time intervals, the electrochemical responses of biofilms to the heavy metals was recorded continuously to monitor the online progression of biofilms at the surface of the modified electrodes $[55,56]$.

\section{Conclusions}

According to the data obtained in this study, Rhodotorula-ALT72 and Rhizobium-MAP7 can survive under stress of heavy metals ions $\mathrm{Cr}(\mathrm{VI})$ and $\mathrm{Cd}(\mathrm{II})$, while the chromium ions are more toxic than cadmium ions to both strains and also could be removed with higher percentage under concentrations 0.1 and $1 \mathrm{mg} / \mathrm{L}$. Bioelectrochemical systems were used effectively to study the dynamic changes and cellular responses to the toxic metal ions. Rhizobium-MAP7 provides higher ability of removal of heavy metals and more resistive to metals ions since cell viability was not inhibited by either the toxic metal ions over the various concentrations than Rhodotorula-ALT72. Moreover, the faradic currents which result from electrochemically active biofilm in presence of heavy metals ions is higher in Rhodotorula-ALT72 than Rhizobium-MAP7 while the untreated cells were still producing higher electrochemical signals. So using the two strains especially Rhizobium-MAP7 support the detection and removal of heavy metals $\mathrm{Cr}(\mathrm{VI})$ and $\mathrm{Cd}(\mathrm{II})$.

Author Contributions: Conceptualization, A.E., R.Y.A.H. and A.S.G.; methodology, A.E. and R.A.A.; validation, A.E., R.Y.A.H., A.S.G., A.N. and H.D.; formal analysis, R.A.A.; investigation, R.A.A.; resources, A.E., A.N. and H.D.; data curation, R.A.A.; writing-original draft preparation, A.E. and R.A.A.; writing-review and editing, A.E., R.Y.A.H., A.S.G., A.N. and H.D.; visualization, A.E., R.Y.A.H. and A.S.G.; supervision, R.A.A.; project administration, A.E.; funding acquisition, A.N. and H.D. All authors have read and agreed to the published version of the manuscript.

Funding: The current work was funded by Taif University Researchers Supporting Project number (TURSP-2020/141), Taif University, Taif, Saudi Arabia.

Institutional Review Board Statement: Not applicable.

Informed Consent Statement: Not applicable.

Data Availability Statement: The data presented in this study are available in within the article.

Conflicts of Interest: The authors declare no conflict of interest.

Sample Availability: Sample of the compounds are not available from the authors.

\section{References}

1. Nies, D.H. Microbial heavy-metal resistance. Appl. Microbiol. Biotechnol. 1999, 51, 730-750. [CrossRef]

2. Roberts, J.R. Metal toxicity in children. Training Manual on Pediatric Environmental Health: Putting it into Practice. Emeryville, CA: Children's Environmental Health Network. Environ. Health Netw. 1999, 1.

3. Okereafor, U.; Makhatha, M.; Mekuto, L.; Uche-Okereafor, N.; Sebola, T.; Mavumengwana, V.J.I. Toxic metal implications on agricultural soils, plants, animals, aquatic life and human health. Int. J. Environ. Res. Public Health 2020, 17, 2204. [CrossRef] 
4. Hasan Abadi, N.; Danesh Pazhooh, M.; Mahdavis Meymand, Z. Determination of Heavy and Mineral Metals in Raw Milk Produced from Livestock in Khatoon-Abad, Shahr-e-Babak, Kerman. Health Dev. J. 2020, 8, 152-162. [CrossRef]

5. Kumar, M.P.; Kumar, D.J.; Kumar, A.; Siregere, N.J.; Venu, T. Comparative Assessment of Surface Soil Contamination Around Bellandur and Kengeri Lakes. In Problematic Soils and Geoenvironmental Concerns; Springer: Berlin/Heidelberg, Germany, 2021; pp. 817-825. [CrossRef]

6. Barbato, R.J.A. Inhibition of Donor and Acceptor Side of Photosystem II by Cadmium Ions. In Approaches to the Remediation of Inorganic Pollutants; Hasanuzzaman, M., Ed.; Springer: Singapore, 2021; pp. 187-196. [CrossRef]

7. Tchounwou, P.B.; Yedjou, C.G.; Patlolla, A.K.; Sutton, D.J.J.M. Heavy metal toxicity and the environment. In Molecular, Clinical and Environmental Toxicology. Experientia Supplementum; Luch, A., Ed.; Springer: Berlin/Heidelberg, Germany, 2012 ; pp. 133-164. [CrossRef]

8. Kojima, Y.; Machida, Y.J.J.E. DNA-protein crosslinks from environmental exposure: Mechanisms of formation and repair. Environ. Mol. Mutagenesis 2020, 61, 716-729. [CrossRef]

9. Lapworth, D.; MacDonald, A.; Kebede, S.; Owor, M.; Chavula, G.; Fallas, H.; Wilson, P.; Ward, J.; Lark, M.; Okullo, J.J.E.R.L. Drinking water quality from rural handpump-boreholes in Africa. Environ. Res. Lett. 2020, 15, 064020. [CrossRef]

10. Shahid, M.; Khalid, S.; Bibi, I.; Bundschuh, J.; Niazi, N.K.; Dumat, C.J.S. A critical review of mercury speciation, bioavailability, toxicity and detoxification in soil-plant environment: Ecotoxicology and health risk assessment. Sci. Total Environ. 2020, 711, 134749. [CrossRef]

11. Pavlaki, M.D.; Morgado, R.G.; Ferreira, V.; Rocha, R.J.; Soares, A.M.; Calado, R.; Loureiro, S.J.W. Cadmium Accumulation and Kinetics in Solea senegalensis Tissues under Dietary and Water Exposure and the Link to Human Health. Water 2021, 13, 522. [CrossRef]

12. Dong, W.; Zhang, Y.; Quan, X.J.C. Health risk assessment of heavy metals and pesticides: A case study in the main drinking water source in Dalian, China. Chemosphere 2020, 242, 125113. [CrossRef] [PubMed]

13. Aguilar, M.; Lloréns, M.; Fernández-Garrido, J.; Pérez-Marín, A.; Ortuño, J.; Meseguer, V.J.I.J. Heavy metals effect on the heterotrophic activity of activated sludge. Int. J. Environ. Sci. Technol. 2020, 17, 3111-3118. [CrossRef]

14. Ambreen, S.; Yasmin, A. Biology, Isolation, Characterization and Identification of Organophosphate Pesticide Degrading Bacterial Isolates and Optimization of their Potential to Degrade Chlorpyrifos. Int. J. Agric. Biol. 2020, 24, 699-706. [CrossRef]

15. Wang, Y.; Zhang, C.; Liu, F.J.F. Antibody developments for metal ions and their applications. Food Agric. Immunol. 2020, 31, 1079-1103. [CrossRef]

16. Uba, G.; Manogaran, M.; Gunasekaran, B.; Halmi, M.I.E.; Abd Shukor, M.Y. Improvement of Ficin-Based Inhibitive Enzyme Assay for Mercury Using Response Surface Methodology and Its Application for Near Real-Time Monitoring of Mercury in Marine Waters. Int. J. Environ. Res. Public Health 2020, 17, 8585. [CrossRef] [PubMed]

17. González-Fernández, A.; Symonds, E.M.; Gallard-Gongora, J.F.; Mull, B.; Lukasik, J.O.; Navarro, P.R.; Aguilar, A.B.; Peraud, J.; Brown, M.L.; Alvarado, D.M.; et al. Relationships among microbial indicators of fecal pollution, microbial source tracking markers, and pathogens in Costa Rican coastal waters. Water Res. 2021, 188, 116507. [CrossRef]

18. Qin, H.; Hu, T.; Zhai, Y.; Lu, N.; Aliyeva, J.J.E.P. The improved methods of heavy metals removal by biosorbents: A review. Environ. Pollut. 2020, 258, 113777. [CrossRef] [PubMed]

19. Kawaka, F.; Muoma, J.J.A.A.S. Distribution and phenotypic characteristics of common bean (Phaseolus vulgaris L.) nodulating bacteria in diverse soils. Acta Agric. Scand. Sect. B Plant Soil Sci. 2020, 70, 564-571. [CrossRef]

20. Biljon, A.H.; Sifi, B. Legume-rhizobia symbiosis under abiotic constraints: Performance system. Agrociencia 2021, 55, 37-61.

21. Mowafy, A.M.; Fawzy, M.M.; Gebreil, A.; Elsayed, A.J.A.A.S. Endophytic Bacillus, Enterobacter, and Klebsiella enhance the growth and yield of maize. Acta Agric. Scand. Sect. B Plant Soil Sci. 2021, 1-10. [CrossRef]

22. Sujkowska-Rybkowska, M.; Kasowska, D.; Gediga, K.; Banasiewicz, J.; Stępkowski, T.J.P. Lotus corniculatus-rhizobia symbiosis under Ni, Co and Cr stress on ultramafic soil. Plant Soil 2020, 451, 459-484. [CrossRef]

23. Alfadaly, R.A.; Elsayed, A.; Hassan, R.Y.; Gebreil, A.S. Study on Removal of Hexavalent and Trivalent Chromium Ions by Microbial cells. Mansoura J. Biol. 2020, 1-8.

24. Kour, D.; Kaur, T.; Devi, R.; Yadav, A.; Singh, M.; Joshi, D.; Singh, J.; Suyal, D.C.; Kumar, A.; Rajput, V.D.J.E.S.; et al. Beneficial microbiomes for bioremediation of diverse contaminated environments for environmental sustainability: Present status and future challenges. Environ. Sci. Pollut. Res. 2021, 1-23. [CrossRef]

25. Sepehri, M.; Khatabi, B.J.M.E. Combination of Siderophore-Producing Bacteria and Piriformospora indica Provides an Efficient Approach to Improve Cadmium Tolerance in Alfalfa. Microb. Ecol. 2021, 81, 717-730. [CrossRef] [PubMed]

26. Kefala, M.I.; Zouboulis, A.I.; Matis, K.A. Biosorption of cadmium ions by Actinomycetes and separation by flotation. Environ. Pollut. 1999, 104, 283-293. [CrossRef]

27. Sağ, Y.J.S. Biosorption of heavy metals by fungal biomass and modeling of fungal biosorption: A review. Sep. Purif. Methods 2001, 30, 1-48. [CrossRef]

28. Spain, O.; Plöhn, M.; Funk, C.J.P.P. The cell wall of green microalgae and its role in heavy metal removal. Physiol. Plant. 2021, 1-10. [CrossRef]

29. Saber, W.I.; El-Naggar, N.E.-A.; El-Hersh, M.S.; El-Khateeb, A.Y.; Elsayed, A.; Eldadamony, N.M.; Ghoniem, A.A. Rotatable central composite design versus artificial neural network for modeling biosorption of $\mathrm{Cr} 6+$ by the immobilized Pseudomonas alcaliphila NEWG-2. Sci. Rep. 2021, 11, 1-15. [CrossRef] [PubMed] 
30. Hassan, R.Y.A.; Bilitewski, U. A viability assay for Candida albicans based on the electron transfer mediator 2, 6dichlorophenolindophenol. Anal. Biochem. 2011, 419, 26-32. [CrossRef]

31. Hassan, R.Y.; Hassan, H.N.; Abdel-Aziz, M.S.; Khaled, E.J.S. Nanomaterials-based microbial sensor for direct electrochemical detection of Streptomyces Spp. Sens. Actuators B Chem. 2014, 203, 848-853. [CrossRef]

32. Mahmoud, R.H.; Abdo, S.M.; Samhan, F.A.; Ibrahim, M.K.; Ali, G.H.; Hassan, R.Y.J.J. Biosensing of algal-photosynthetic productivity using nanostructured bioelectrochemical systems. J. Chem. Technol. Biotechnol. 2020, 95, 1028-1037. [CrossRef]

33. Hassan, R.Y.; Wollenberger, U.J.E. Direct Determination of Bacterial Cell Viability Using Carbon Nanotubes Modified Screenprinted Electrodes. Electroanalysis 2019, 31, 1112-1117. [CrossRef]

34. Cecconet, D.; Callegari, A.; Capodaglio, A.G.J.E. Bioelectrochemical systems for removal of selected metals and perchlorate from groundwater: A review. Energies 2018, 11, 2643. [CrossRef]

35. Nancharaiah, Y.; Mohan, S.V.; Lens, P.J.B.T. Metals removal and recovery in bioelectrochemical systems: A review. Bioresour. Technol. 2015, 195, 102-114. [CrossRef] [PubMed]

36. Wesolowski, J.; Hassan, R.Y.; Hodde, S.; Bardroff, C.; Bilitewski, U.J.A. Sensing of oxygen in microtiter plates: A novel tool for screening drugs against pathogenic yeasts. Anal. Bioanal. Chem. 2008, 391, 1731-1737. [CrossRef] [PubMed]

37. Mustafa, F.; Hassan, R.Y.A.; Andreescu, S. Multifunctional Nanotechnology-Enabled Sensors for Rapid Capture and Detection of Pathogens. Sensors 2017, 17, 2121. [CrossRef] [PubMed]

38. Santoro, C.; Arbizzani, C.; Erable, B.; Ieropoulos, I. Microbial fuel cells: From fundamentals to applications. A review. J. Power Sources 2017, 356, 225-244. [CrossRef] [PubMed]

39. Cui, S.; Li, M.; Hassan, R.Y.A.; Heintz-Buschart, A.; Wang, J.; Bilitewski, U. Inhibition of Respiration of Candida albicans by Small Molecules Increases Phagocytosis Efficacy by Macrophages. mSphere 2020, 5, e00016-20. [CrossRef] [PubMed]

40. Mahmoud, R.H.; Samhan, F.A.; Ali, G.H.; Ibrahim, M.K.; Hassan, R.Y.A. Assisting the biofilm formation of exoelectrogens using nanostructured microbial fuel cells. J. Electroanal. Chem. 2018, 824, 128-135. [CrossRef]

41. Selim, H.M.M.; Kamal, A.M.; Ali, D.M.M.; Hassan, R.Y.A. Bioelectrochemical Systems for Measuring Microbial Cellular Functions. Electroanalysis 2017, 29, 1498-1505. [CrossRef]

42. Sedki, M.; Hassan, R.Y.A.; Hefnawy, A.; El-Sherbiny, I.M. Sensing of bacterial cell viability using nanostructured bioelectrochemical system: rGO-hyperbranched chitosan nanocomposite as a novel microbial sensor platform. Sens. Actuators B Chem. 2017, 252, 191-200. [CrossRef]

43. Šefčovičová, J.; Tkac, J. Application of nanomaterials in microbial-cell biosensor constructions. Chem. Pap. 2015, 69, 42-53. [CrossRef]

44. Peixoto, L.; Min, B.; Martins, G.; Brito, A.G.; Kroff, P.; Parpot, P.; Angelidaki, I.; Nogueira, R. In situ microbial fuel cell-based biosensor for organic carbon. Bioelectrochemistry 2011, 81, 99-103. [CrossRef]

45. Abrevaya, X.C.; Sacco, N.J.; Bonetto, M.C.; Hilding-Ohlsson, A.; Cortón, E. Analytical applications of microbial fuel cells. Part I: Biochemical oxygen demand. Biosens. Bioelectron. 2015, 63, 580-590. [CrossRef] [PubMed]

46. Chouler, J.; Cruz-Izquierdo, Á.; Rengaraj, S.; Scott, J.L.; Di Lorenzo, M. A screen-printed paper microbial fuel cell biosensor for detection of toxic compounds in water. Biosens. Bioelectron. 2018, 102, 49-56. [CrossRef] [PubMed]

47. Sedki, M.; Hassan, R.Y.A.; Andreescu, S.; El-Sherbiny, I.M. Online-monitoring of biofilm formation using nanostructured electrode surfaces. Mater. Sci. Eng. C 2019, 100, 178-185. [CrossRef] [PubMed]

48. Hassan, R.Y.A.; Febbraio, F.; Andreescu, S. Microbial Electrochemical Systems: Principles, Construction and Biosensing Applications. Sensors 2021, 21, 1279. [CrossRef] [PubMed]

49. Botsford, J.L. A simple method for determining the toxicity of chemicals using a bacterial indicator organism. Environ. Toxicol. 1999, 14, 285-289. [CrossRef]

50. Motlagh, A.M.; Yang, Z. Detection and occurrence of indicator organisms and pathogens. Water Environ. Res 2019, 91, 1402-1408. [CrossRef]

51. Basak, G.; Lakshmi, V.; Chandran, P.; Das, N. Removal of Zn(II) from electroplating effluent using yeast biofilm formed on gravels: Batch and column studies. J. Environ. Health Sci. Eng. 2014, 12, 8. [CrossRef]

52. Grujić, S.; Vasić, S.; Radojević, I.; Čomić, L.; Ostojić, A. Comparison of the Rhodotorula mucilaginosa Biofilm and Planktonic Culture on Heavy Metal Susceptibility and Removal Potential. Water Air Soil Pollut. 2017, 228, 73. [CrossRef]

53. El-Raheem, H.A.; Hassan, R.Y.A.; Khaled, R.; Farghali, A.; El-Sherbiny, I.M. Polyurethane-doped platinum nanoparticles modified carbon paste electrode for the sensitive and selective voltammetric determination of free copper ions in biological samples. Microchem. J. 2020, 155, 104765. [CrossRef]

54. Mahmoud, R.H.; Samhan, F.A.; Ibrahim, M.K.; Ali, G.H.; Hassan, R.Y.A. Boosting the cathode function toward the oxygen reduction reaction in microbial fuel cell using nanostructured surface modification. Electrochem. Sci. Adv. 2021, 1, e2000002. [CrossRef]

55. Sedki, M.; Hefnawy, A.; Hassan, R.Y.; El-Sherbiny, I.M. Core-shell hyperbranched chitosan nanostructure as a novel electrode modifier. Int. J. Biol. Macromol. 2016, 93, 543-546. [CrossRef] [PubMed]

56. Hassan, R.Y.; Bilitewski, U.J.B. Bioelectronics, Direct electrochemical determination of Candida albicans activity. Biosens. Bioelectron. 2013, 49, 192-198. [CrossRef] [PubMed] 